\title{
Two new rapacious nematodes from intertidal sediments, Gammanema magnum sp. nov. and Synonchium caudatubatum sp. nov. (Nematoda, Selachinematidae)
}

\author{
Benze SHI ${ }^{1} \&$ Kuidong XU ${ }^{2, *}$ \\ ${ }^{1,2}$ Department of Marine Organism Taxonomy and Phylogeny, Institute of Oceanology, \\ Chinese Academy of Sciences, Qingdao 266071, China. \\ ${ }^{2}$ Laboratory for Marine Biology and Biotechnology, Qingdao National Laboratory \\ for Marine Science and Technology, Qingdao 266071, China. \\ ${ }^{2}$ University of Chinese Academy of Sciences, Beijing 100049, China. \\ *Corresponding author: kxu@qdio.ac.cn \\ ${ }^{1}$ Email: shibenze@foxmail.com \\ ${ }^{1}$ urn:lsid:zoobank.org:author:96263530-6EA2-4237-9029-A65835B9AF36 \\ ${ }^{2}$ urn:lsid:zoobank.org:author:7338893E-D622-4301-8E76-3A412AFFC15E
}

\begin{abstract}
Two new species of the family Selachinematidae Cobb, 1915 from an intertidal sandy flat in the East China Sea are described. Both species are distinct rapacious nematodes, preying on other nematodes. Gammanema magnum sp. nov. is characterized by its leaf-like labial setae, large loop-shaped amphideal fovea in the male and small spiral ones in the female, an anterior buccal cavity reinforced by 12 rhabdia, each rhabdion with about six denticles, and two unequally long spicules. Gammanema magnum sp. nov. is a striking species, exhibiting extreme sexual dimorphism in the amphideal fovea, but lacking a gubernaculum or precloacal supplements, all features by which it can be differentiated from congeneric species. Synonchium caudatubatum sp. nov. is characterized by a posterior buccal cavity, with three mandibles each with a large tooth flanked by three smaller teeth on both sides, a transverse oval-shaped multispiral amphideal fovea, and a bluntly rounded tail with a protuberant caudal duct. Synonchium caudatubatum sp. nov. is unique in the genus in having a protuberant caudal duct in the tail end. Furthermore, it differs from its congeners by its mandibles, which have seven teeth each. Synonchium caudatubatum sp. nov. lacks a gubernaculum and a precloacal supplement, both features present in congeners except $S$. depressum Gerlach, 1954.
\end{abstract}

Keywords. East China Sea, marine nematode, morphology, new species, sandy sediment.

Shi B. \& Xu K. 2018. Two new rapacious nematodes from intertidal sediments, Gammanema magnum sp. nov. and Synonchium caudatubatum sp. nov. (Nematoda, Selachinematidae). European Journal of Taxonomy 405: 1-17. https://doi.org/10.5852/ejt.2018.405

\section{Introduction}

Within the order Chromadorida Chitwood, 1933, the family Selachinematidae Cobb, 1915 is distinctly characterized by a large buccal cavity divided into two compartments. Nematodes of Selachinematidae 
are mostly reported from relatively coarse sediments in shallow marine environments worldwide and may also occur in deep-sea habitats (Leduc 2013; Miljutin et al. 2010; Okhlopkov 2002; Tchesunov \& Okhlopkov 2006). Many of them are repeatedly reported as predators of other nematodes, and may play a key role in the ecosystems of coarse sandy sediments given their high diversity and high numbers (Okhlopkov 2003; Tchesunov \& Okhlopkov 2006).

The taxonomy of Selachinematidae was revised by Gerlach (1964) based on the classification of the buccal cavity structure. Later, Gerlach \& Riemann (1973) differentiated two subfamilies within the Selachinematidae based on buccal cavity and cuticular structures. The subfamily Choniolaiminae Schuurmans-Stekhoven \& Adam, 1931 is characterized by a buccal cavity reinforced by cuticularized rhabdia in both compartments: six well-developed rhabdia in the broad cup-shaped anterior chamber and three weaker rhabdia in the cylindrical posterior chamber (Tchesunov \& Okhlopkov 2006). Members of the subfamily Selachinematinae Cobb, 1915 have a buccal cavity with a reduced anterior chamber and a posterior chamber with mandibles. At present, 15 genera are included in the family Selachinematidae (Vanaverbeke 2015).

So far, only five selachinematid species belonging to three genera, Halichoanolaimus de Man, 1886; Richtersia Steiner, 1916 and Synonchiella Cobb, 1933, have ever been reported from the sea areas of China (Liu 2008; Fu et al. 2013). In this paper we describe two new species of Selachinematidae from a sand beach in the East China Sea: Gammanema magnum sp. nov. (Choniolaiminae) and Synonchium caudatubatum sp. nov. (Selachinematinae). Both species are rapacious and prey on other nematodes. This is also the first record of both genera in the sea areas of China.

\section{Material and methods}

Sediment samples were collected from the Dasha'ao Sand Beach in the Nanji Islands National Marine Natural Reserve in the East China Sea $\left(27^{\circ} 27.76^{\prime} \mathrm{N}, 121^{\circ} 3.48^{\prime}\right.$ E) in May 2014. Samples were fixed with formalin ( $5 \%$ final concentration) in filtered sea water. The fixed samples were stained with $0.1 \%$ Rose Bengal for 12 hours (Higgins \& Thiel 1988) and subsequently rinsed on a $500 \mu \mathrm{m}$ sieve to remove large particles and on a $31 \mu \mathrm{m}$ sieve to retain meiofauna. Meiofauna was extracted from the remaining sediments using Ludox HS 40 by centrifugation (Platt \& Warwick 1983) and sorted to higher taxa under a dissecting microscope. Nematodes were transferred into 9:1 (v/v) solution of 50\% alcohol-glycerol in a cavity block to slowly evaporate to pure glycerol, and then mounted into permanent slides (Platt \& Warwick 1983).

Species descriptions were made from glycerol mounts (Platt \& Warwick 1983) using a differential interference contrast microscope (Nikon E80i). Line drawings were made with the aid of a drawing device. Type specimens have been deposited in the Marine Biological Museum of Chinese Academy of Sciences, Qingdao, China (MBMCAS). All measurements are in $\mu \mathrm{m}$, and all curved structures are measured along the arc. The terminology used for describing the arrangement of morphological features follows Coomans (1979).

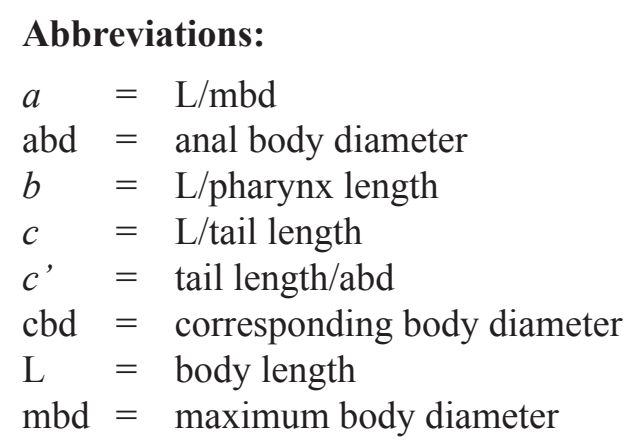




$$
\begin{aligned}
& \mathrm{V}=\text { distance from anterior end to vulva } \\
& \mathrm{V} \%=\mathrm{V} \times 100 / \mathrm{L}
\end{aligned}
$$

\title{
Results
}

\author{
Order Chromadorida Chitwood, 1933 \\ Family Selachinematidae Cobb, 1915 \\ Subfamily Choniolaiminae Schuurmans-Stekhoven \& Adam, 1931 \\ Genus Gammanema Cobb, 1920 \\ Gammanema magnum sp. nov. \\ urn:1sid:zoobank.org:act:C86AD66F-ECB9-48A8-8D6A-15D777EB9749
}

Figs 1-4; Table 1

\section{Diagnosis}

Body cylindrical, length $2540-4085 \mu \mathrm{m}$. Six short leaf-like inner labial setae with broad base, six long leaf-shaped outer labial setae with broad base and four slender cephalic setae arranged in three circlets. Anterior buccal cavity broad and cup-shaped, reinforced by 12 sclerotized rhabdia, each rhabdion with about six denticles at posterior end; posterior buccal cavity narrow and cylindrical with six broad rhabdia, surrounded by pharyngeal tissue. Amphideal fovea exhibiting extreme sexual dimorphism: large loop in about 1.3 turns occupying $79-82 \%$ of corresponding body diameter in males and very small spiral in about two turns occupying $12-14 \%$ of corresponding body diameter in females. Pharynx with anterior end slightly swelling, but not bulb-like enlarged. Two opposed testes. Sperm globular to oval. Two spicules unequally long and slightly curved, with left spicule (51-56 $\mu \mathrm{m}$ long) slightly shorter than right one (62-69 $\mu \mathrm{m}$ long). Two reflexed ovaries. Spermatheca large, filled up with sperm. Three caudal glands with spinneret. Tail short and conical.

\section{Etymology}

The specific epithet is from the Latin adjective 'magnus' (large) and refers to two distinct features of the species, i.e., the large body size and the large amphideal fovea in male.

\section{Material examined}

\section{Holotype}

EAST CHINA SEA: ${ }^{\wedge}$, Nanji Islands, Dasha' ao Beach, $27^{\circ} 27.76^{\prime} \mathrm{N}, 121^{\circ} 3.48^{\prime} \mathrm{E}$, May 2014 , intertidal sandy sediment, temperature $22^{\circ} \mathrm{C}$, salinity 28 psu during sampling, median particle diameter of sediment about $612 \mu \mathrm{m}$ (coarse sand), sediment organic matter content about 2.5\%, Benze Shi and Kuidong Xu leg. (MBMCAS NJ-20140513-73).

\section{Paratypes}

EAST CHINA SEA: $2 \hat{\jmath}, 7$ + + , same collecting data as for holotype (MBMCAS NJ-20140513-22, MBMCAS NJ-20140513-71, MBMCAS NJ-20140513-73, MBMCAS NJ-20140513-83, MBMCAS NJ-20140513-84).

\section{Description}

Measurements. See Table 1.

BoDy. Cylindrical. Cuticle thick and distinct annulated, rows of punctuations on the annules, without lateral differentiation (Figs 1A, 2D, 3A). Head blunt with six pairs of thin, membrane-like cuticle extensions. Anterior sensilla in three circles: six inner labial setae leaf-shaped with a broad base, six outer 
Table 1. Morphometrics (measurements in $\mu \mathrm{m}$ ) of Gammanema magnum sp. nov. Mean values for female paratypes are shown in brackets.

\begin{tabular}{|c|c|c|c|}
\hline \multirow{2}{*}{ Characters } & \multirow{2}{*}{ Holotype } & \multicolumn{2}{|c|}{ Paratypes } \\
\hline & & Males $(n=2)$ & Females $(n=7)$ \\
\hline Body length & 4085 & $2900-3500$ & $2540-3145(2890)$ \\
\hline Maximum body diameter & 78 & $60-67$ & $85-103(92)$ \\
\hline$a$ & 52.4 & $48.3-52.2$ & $28.2-33.1(31.3)$ \\
\hline$b$ & 12.7 & $9.6-12.8$ & $7.9-9.3(8.7)$ \\
\hline$c$ & 33.2 & $31-35.8$ & $24.8-29.9(29.8)$ \\
\hline$c^{\prime}$ & 2.1 & $1.4-2$ & $1.1-1.8(1.6)$ \\
\hline Head diameter & 51 & $50-51$ & $72-85(77.6)$ \\
\hline Inner labial setae length & 16 & $15-16$ & $10-14(11)$ \\
\hline Outer labial setae length & 25 & $22-25$ & $20-21(20)$ \\
\hline Cephalic setae length & 35 & $31-35$ & $40-45(43)$ \\
\hline Amphideal fovea from anterior end & 25 & $18-23$ & $39-46(41)$ \\
\hline Amphideal fovea length & 43 & $38-39$ & $9-10(10)$ \\
\hline Amphideal fovea width & 45 & $42-45$ & $9-10(10)$ \\
\hline cbd at the amphideal fovea & 55 & $52-57$ & $72-85(76)$ \\
\hline Amphideal fovea width/cbd & $82 \%$ & $79-81 \%$ & $12-14 \%(13)$ \\
\hline Nerve ring from anterior end & 140 & 122 & $130-165(146)$ \\
\hline cbd at nerve ring & 60 & $52-56$ & 77-78 (77) \\
\hline Pharynx length & 321 & $273-301$ & $311-348(335)$ \\
\hline cbd at the cardia & 60 & $50-55$ & $65-75(73)$ \\
\hline Vulva from anterior end & - & - & $1575-2125(1915)$ \\
\hline $\mathrm{V} \%$ & - & - & $62-67(66 \%)$ \\
\hline cbd at vulva & - & - & 80-103 (90) \\
\hline Left spicule length & 56 & $51-53$ & - \\
\hline Right spicule length & 64 & $62-69$ & - \\
\hline Anal body diameter & 58 & $55-56$ & $59-70(62)$ \\
\hline Tail length & 123 & $81-113$ & $80-110(97)$ \\
\hline
\end{tabular}

labial setae leaf-shaped with a broad base and four slender cephalic setae (Figs 1A-B, 2B-C, 3A-B). Buccal cavity spacious, divided into two portions. Anterior buccal cavity broad, cup-shaped, with 12 cuticularized rhabdia, each rhabdion with about six pointed denticles at its posterior end. Posterior buccal cavity narrow and cylindrical, surrounded by six broad rhabdia (Figs 1B, 2C, 3B, 4A). Pharynx cylindrical, with slight anterior end swelling, not bubliform, surrounding the posterior buccal cavity, without posterior bulb. Numerous cells surrounding the pharynx. Intestine cells large, filled of orangebrown inclusions. Intestine lumen with irregular and variable appearance. Prey nematode species often observed in the intestine are probably members of Epacanthion Wieser, 1953, as observed in the intestine 



Fig. 1. Gammanema magnum sp. nov., holotype, $\widehat{\jmath}$. A. Surface view of head, showing the very large amphideal fovea, six leaf-like outer labial setae, four slender cephalic and four slender cervical setae, and the transverse rows of punctuations. B. Inside view of head, showing the broad anterior buccal cavity reinforced by cuticularized rhabdia each with about six pointed denticles at the posterior end, the narrow and cylindrical posterior buccal cavity surrounded by six broad rhabdia, and the anterior pharynx swelling but not forming a bulb. C. Neck region, showing the pharynx surrounded by numerous cells, nerve ring, the large intestine cells filled of inclusions, and the irregular intestine lumen. D. Posterior region, showing the opposed testes with globular to oval sperm cells (arrowheads), the unequally long spicules, the caudal glands (arrows), and the short and conical tail. E. Two spicules. Scale bars: $50 \mu \mathrm{m}$. 





the cylindrical pharynx with anterior swollen portion, the two reflexed ovaries, the caudal glands with spinneret, and the conical tail. B. Surface view of head, showing the very small multispiral amphideal fovea, leaf-like inner (arrowheads) and outer (arrows) labial setae, four slender cephalic and four slender cervical setae, and the transverse rows of punctuations. C. Inside view of head, showing similar features as the male holotype. D. Cuticle with transverse rows of punctuations. E. Vulva. Scale bars: $A=100 \mu \mathrm{m}$, $\mathrm{B}-\mathrm{E}=50 \mu \mathrm{m}$. 

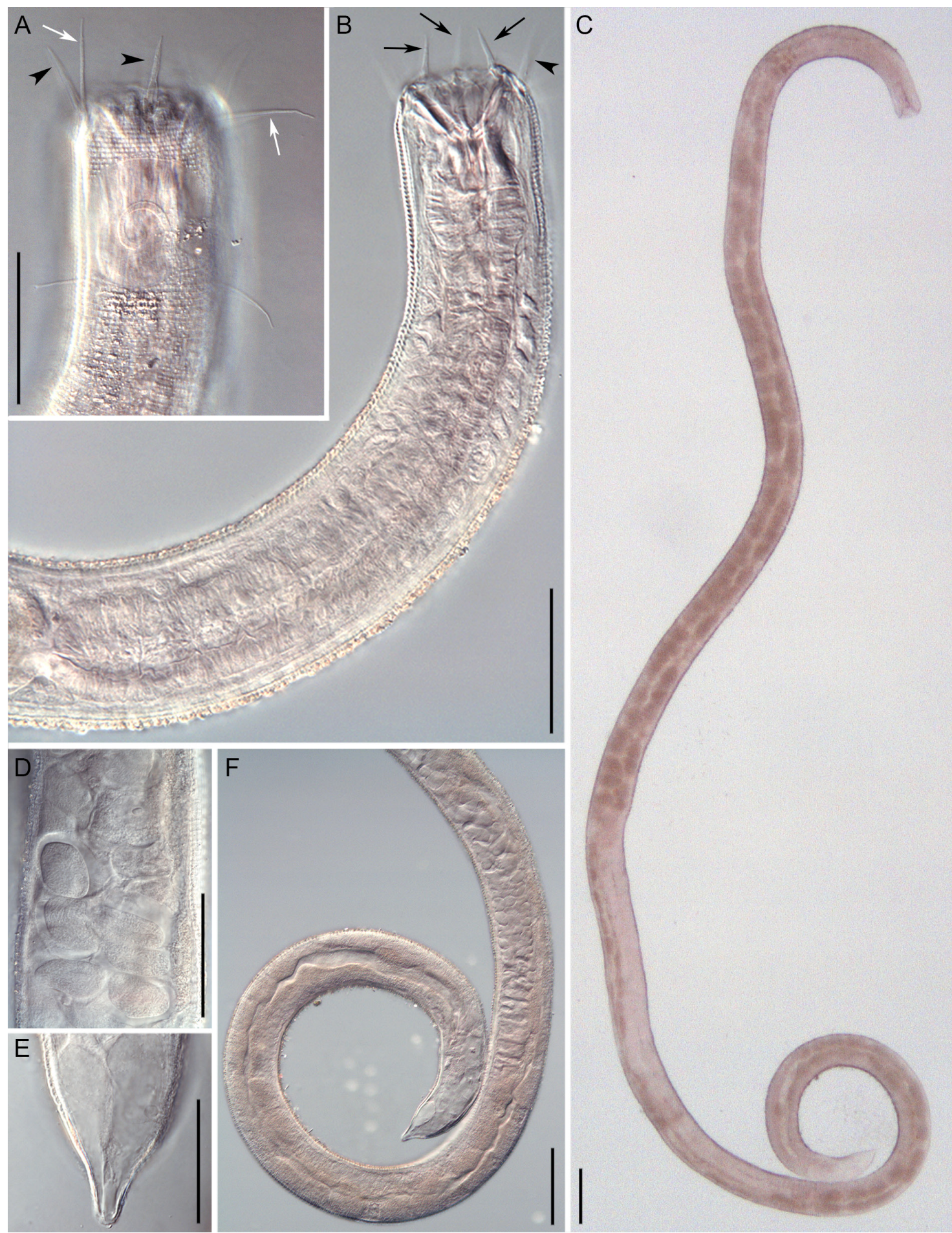

Fig. 3. Gammanema magnum sp. nov., holotype, $\widehat{\jmath}$. A. Surface view of head, showing the large amphideal fovea, outer labial setae (arrowheads), the slender cephalic setae (white arrows), and the transverse rows of punctuations. B. Neck region, showing the leaf-like inner labial setae (black arrows), the broad anterior buccal cavity reinforced by cuticularized rhabdia, each with about six pointed denticles at each posterior end, the narrow and cylindrical posterior buccal cavity surrounded by six broad rhabdia. C. Overview, showing the slender body and conical tail. D. Globular to oval sperm cells. E. Two unequally long spicules. F. Posterior region, showing the opposed testes with globular to oval sperm, the caudal glands with spinneret, and the conical tail. Scale bars: A-B $=50 \mu \mathrm{m}, \mathrm{C}-\mathrm{F}=100 \mu \mathrm{m}$. 

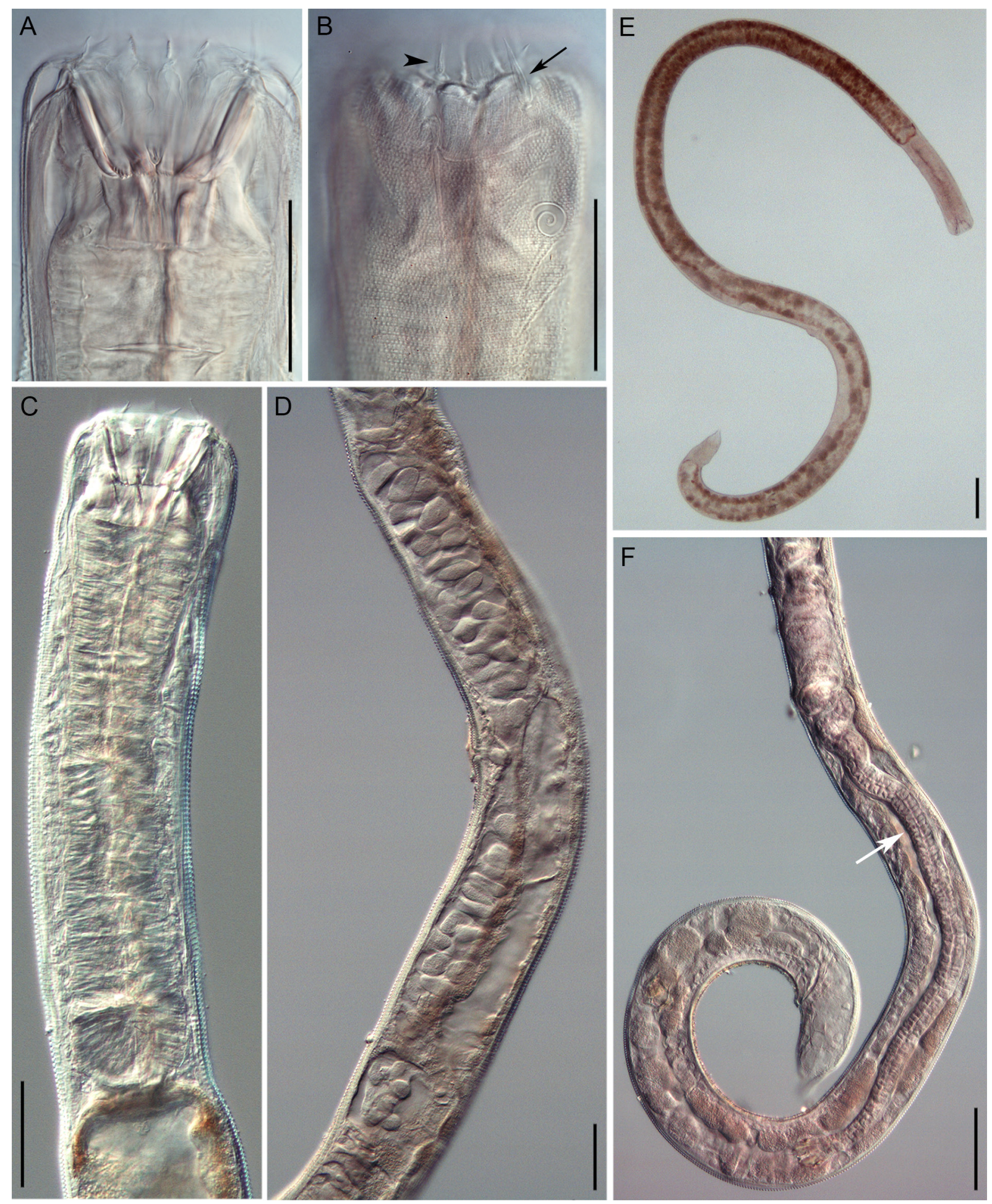

Fig. 4. Gammanema magnum sp. nov., paratype,, . A-B. Head, showing the small multispiral amphideal fovea, the leaf-like inner (arrowhead) and outer (black arrow) labial setae, the transverse rows of punctuations, and the buccal cavity as drawn in Fig. 2. C. Anterior region, showing the cylindrical pharynx surrounded by numerous cells, with anterior end swelling but not forming a bulb. D. Large spermatheca with globular to oval sperm cells. E. Overview, showing the slender body and conical tail. F. The intestine contains a prey nematode, likely a member of Epacanthion Wieser, 1953 (white arrow). Scale bars: $50 \mu \mathrm{m}$. 
SHI B. \& XU K., Two new rapacious nematodes from an intertidal flat

of a paratype specimen (Fig. 4F). Three caudal glands with spinneret. Tail short and conical (Figs 1D, 2A, 3E).

\section{Male}

Amphideal fovea large loop-shaped, in about 1.3 turns, covering $79-82 \%$ of corresponding body diameter (Figs 1A, 3A). Two opposed testes, situated ventrally left to the intestine. Sperm cells globular to oval (Figs 1D, 3D, F). Two spicules unequally long and slightly curved, with left spicule slightly shorter than right one (Fig. 1E). Gubernaculum absent. Precloacal supplement absent.

\section{Female}

Similar to male in body shape. Outer labial setae slightly shorter than in male but cephalic setae slightly longer than in male. Amphideal fovea small spiral, in about two turns, covering 12-14\% of corresponding body diameter (Figs 2B, 4B). Two reflexed ovaries. Vulva a transverse slit, located at $62-67 \%$ of body. Vagina surrounded by well-developed constrictor muscles. Uterus broad. Spermatheca large, filled up with sperm (Fig. 4D).

\section{Remarks}

The new species is assigned to the genus Gammanema Cobb, 1920 based on its broad and cup-shaped anterior buccal cavity reinforced by 12 cuticularized rhabdia each with about six pointed denticles at posterior end and a narrow and cylindrical posterior buccal cavity surrounded by six broad rhabdia. The genus Gammanema now contains 13 valid species (Leduc 2013). Among these, sexual dimorphism in the amphideal fovea occurs in species where both males and females are known. However, the males of two species, G. mediterraneum Vitiello, 1970 and G. cancellatum Gerlach, 1955, remain hitherto unknown. Compared to the females, Gammanema magnum sp. nov. differs from G. mediterraneum in the greater body size, which is four times larger, the leaf-like labial setae (vs papillate) and the absence (vs presence) of long somatic setae. It differs from G. cancellatum in the leaf-like outer labial setae distinctly shorter than the cephalic setae (vs slender outer labial setae longer than the cephalic setae).

Gammanema magnum sp. nov. is a striking species exhibiting extreme sexual dimorphism in the amphideal fovea: large loop-shaped in males and small spiral in females. Only G. fennicum Gerlach, 1953, G. conicauda Gerlach, 1953 and G. agglutinans Leduc, 2013 show such dimorphism. However, Gammanema magnum sp. nov. differs distinctly from the three aforementioned species by the two unequally long spicules without gubernaculum (vs equal sized spicules with gubernaculum) and the lack of precloacal supplement (vs with supplements). The new species differs also distinctly from G. conicauda and G. agglutinans by its larger amphideal fovea in males (in 1.75 turns covering 79 $82 \%$ of cbd vs a single loop covering $34-41 \%$ of cbd and a small open loop covering $28-29 \%$ of cbd, respectively) and the leaf-like labial setae (vs slender and conical setae, respectively).

Subfamily Selachinematinae Cobb, 1915

Genus Synonchium Cobb, 1920

Synonchium caudatubatum sp. nov. urn:1sid:zoobank.org:act:CDAACB82-D03D-4808-9B13-6B1AADFC9CF0

Figs 5-7; Tables 2-3

\section{Diagnosis}

Body cylindrical, length 2270-2760 $\mu \mathrm{m}$. Labial and cephalic sensilla papillate. Anterior buccal cavity reduced, surrounded by 12 rhabdia, posterior buccal cavity with three mandibles each composed of one large tooth flanked by three smaller teeth on both sides. Amphideal fovea flattened multispiral, in about 
three turns. Pharynx largely cylindrical with slight anterior swelling but not forming a bulb. Two opposed testes, sperm globular to oval. Two spicules sclerotized and almost straight, 55-60 $\mu \mathrm{m}$ long. Two reflexed ovaries. Three caudal glands with spinneret. Tail bluntly rounded, with a protuberant caudal duct.

\section{Etymology}

The specific epithet is a composite of the Latin noun 'cauda' (tail) and the Latin adjective 'tubatus' (with tube), referring to the presence of a protuberant caudal duct, a main feature of the species.

\section{Material examined}

Holotype

EAST CHINA SEA: ${ }^{`}$, Nanji Islands, Dasha' ao Beach, $27^{\circ} 27.76^{\prime} \mathrm{N}, 121^{\circ} 3.48^{\prime}$ E, May 2014, intertidal sandy sediment, temperature $22^{\circ} \mathrm{C}$, salinity at $28 \mathrm{psu}$ during sampling, median particle diameter of sediment about $612 \mu \mathrm{m}$ (coarse sand), sediment organic matter content about 2.5\%, Benze Shi and Kuidong Xu leg. (MBMCAS NJ-20140513-105).

\section{Paratypes}

EAST CHINA SEA: $4 \hat{\partial} \hat{\partial}, 5$ q $q$, same collecting data as for holotype (MBMCAS NJ-20140513-9, MBMCAS NJ-20140513-30, MBMCAS NJ-20140513-73, MBMCAS NJ-20140513-83, MBMCAS NJ-20140513-84, MBMCAS NJ-20140513-105).

\section{Description}

\section{MeAsurements. See Table 2.}

BoDy. Cylindrical. Anterior end of head almost truncate. Labial region with 12 lobes and six pairs of thin, membrane-like cuticle extensions (Figs 5D-E, 6A). Six inner labial papillae minute and conical situated on the lips, six outer labial papillae and four cephalic papillae large and conical. Cuticle thick and distinctly annulated, with lateral pores; each annule with a transverse row of punctations, without lateral differentiation. Amphideal fovea multispiral in about three turns, transverse oval-shaped (Figs 5D, 6B). Buccal cavity in two compartments: anterior one with 12 cuticularized rhabdia; posterior one surrounded by pharyngeal tissue, with three mandibles each bearing a large tooth flanked by three smaller teeth to each side (Fig. 5E). Pharynx cylindrical, with anterior end swollen. Nerve ring surrounding pharynx near its middle portion. Cardia flattened. Intestine cells large, filled with numerous small granules. Intestine lumen of irregular and variable appearance, containing remnants such as spicules and mandibles of prey nematodes (Fig. 7C). Three caudal glands with spinneret. Tail bluntly rounded, with a protuberant caudal duct (Fig. 7C).

\section{Male}

Two opposed testes short and broad, with anterior one slightly larger than posterior one, situated ventrally left to the intestine. Sperm cells globular to oval. Spicules sclerotized, almost straight, with proximal end weakly cephalated, distal end pointed and slightly bent ventrally. Gubernaculum and precloacal supplement absent.

\section{Female}

Similar to male except for reproductive system and sexual features. Two reflexed ovaries. Vulva a transverse slit in ventral view, located at posterior half of body (about 60\%). Vagina short. Uterus broad.

\section{Remarks}

Synonchium Cobb, 1920 is characterized by the posterior buccal cavity equipped with three mandibles each composed of a large tooth flanked by several teeth and transverse oval-shaped multispiral amphideal fovea. The genus now contains nine valid species (Heyns \& Swart 1995; Vinciguerra \& Orselli 1997; 
SHI B. \& XU K., Two new rapacious nematodes from an intertidal flat

Table 2. Morphometrics (measurements in $\mu \mathrm{m}$ ) of Synonchium caudatubatum sp. nov. Figures between brackets represent mean values.

\begin{tabular}{|c|c|c|c|}
\hline \multirow{2}{*}{ Characters } & \multirow{2}{*}{ Holotype } & \multicolumn{2}{|c|}{ Paratypes } \\
\hline & & Males $(n=4)$ & Females $(n=5)$ \\
\hline Body length & 2270 & $2460-2600(2530)$ & $2195-2760(2557)$ \\
\hline$a$ & 31.5 & $33.3-36.1(34.3)$ & $26.8-28.5(27.3)$ \\
\hline$b$ & 7.6 & $8.1-8.7(8.4)$ & $7.1-9.2(8)$ \\
\hline$c$ & 41.3 & $43.9-47.3(45.8)$ & $33.8-37.8(36)$ \\
\hline$c^{\prime}$ & 1 & $1(1)$ & $1-1.1(1)$ \\
\hline Head diameter & 63 & $58-62(61)$ & $70-75(73.3)$ \\
\hline Mandible length & 28 & $25-29(27)$ & $28-30(29.3)$ \\
\hline Amphideal fovea from anterior end & 20 & $20-21(21)$ & $20-27(24.3)$ \\
\hline Amphideal fovea length & 9 & $10-12(11)$ & $9-10(10)$ \\
\hline Amphideal fovea width & 19 & $20-21(21)$ & $16-18(18)$ \\
\hline cbd at amphideal fovea & 69 & $63-66(65)$ & $76-85$ (77) \\
\hline Amphideal fovea width/cbd & $28 \%$ & $31 \%-32 \%(32 \%)$ & $19 \%-26 \%(23 \%)$ \\
\hline Nerve ring from anterior end & 125 & $120-130(125.8)$ & $122-145(135)$ \\
\hline cbd at nerve ring & 70 & $64-69(67)$ & $78-83(80)$ \\
\hline Pharynx length & 300 & 300-308 (304) & $300-327(318)$ \\
\hline cbd at cardia & 72 & $65-70(68)$ & $75-90(83)$ \\
\hline Maximum body diameter & 72 & $71-77(74)$ & $82-103(94)$ \\
\hline Vulva from anterior end & - & - & $1271-1653(1508)$ \\
\hline $\mathrm{V} \%$ & - & - & $58-60(59)$ \\
\hline cbd at vulva & - & - & $78-93(84)$ \\
\hline Spicule length & 57 & $55-62(57.3)$ & - \\
\hline Anal body diameter & 53 & $55-57(55.5)$ & $65-70(68)$ \\
\hline Tail length & 55 & $55-56(55.3)$ & $65-75(71)$ \\
\hline
\end{tabular}

Kamran et al. 2009). Synonchium caudatubatum sp. nov. is unique in the genus by having a protuberant caudal duct in the tail end. The new species also differs from congeners by its mandibles, each with seven teeth, while all other known members have either three or five teeth (Table 3). Synonchium caudatubatum sp. nov. lacks a gubernaculum and a precloacal supplement; both features occur in congeners except S. depressum Gerlach, 1954, a species with a conical tail.

\section{Discussion}

The two new species discovered in beach sand from the East China Sea represent the two subfamilies of Selachinematidae. Both species have a robust body, a broad truncated cephalic end and a spacious buccal cavity with well-developed cuticularized rhabdia and denticles or mandibles. Warwick (1971) indicates there is an increase in the dominance of predatory or omnivorous nematode species in sandy sediments. This is clearly shown by the nematode community in the Dasha'ao sand beach, where predatory nematodes dominated the meiofaunal assemblages contributing to about $62 \%$ of the total meiofaunal abundance. Among these nematodes, Thoracostomopsidae Filipjev, 1927 are the most predominant 


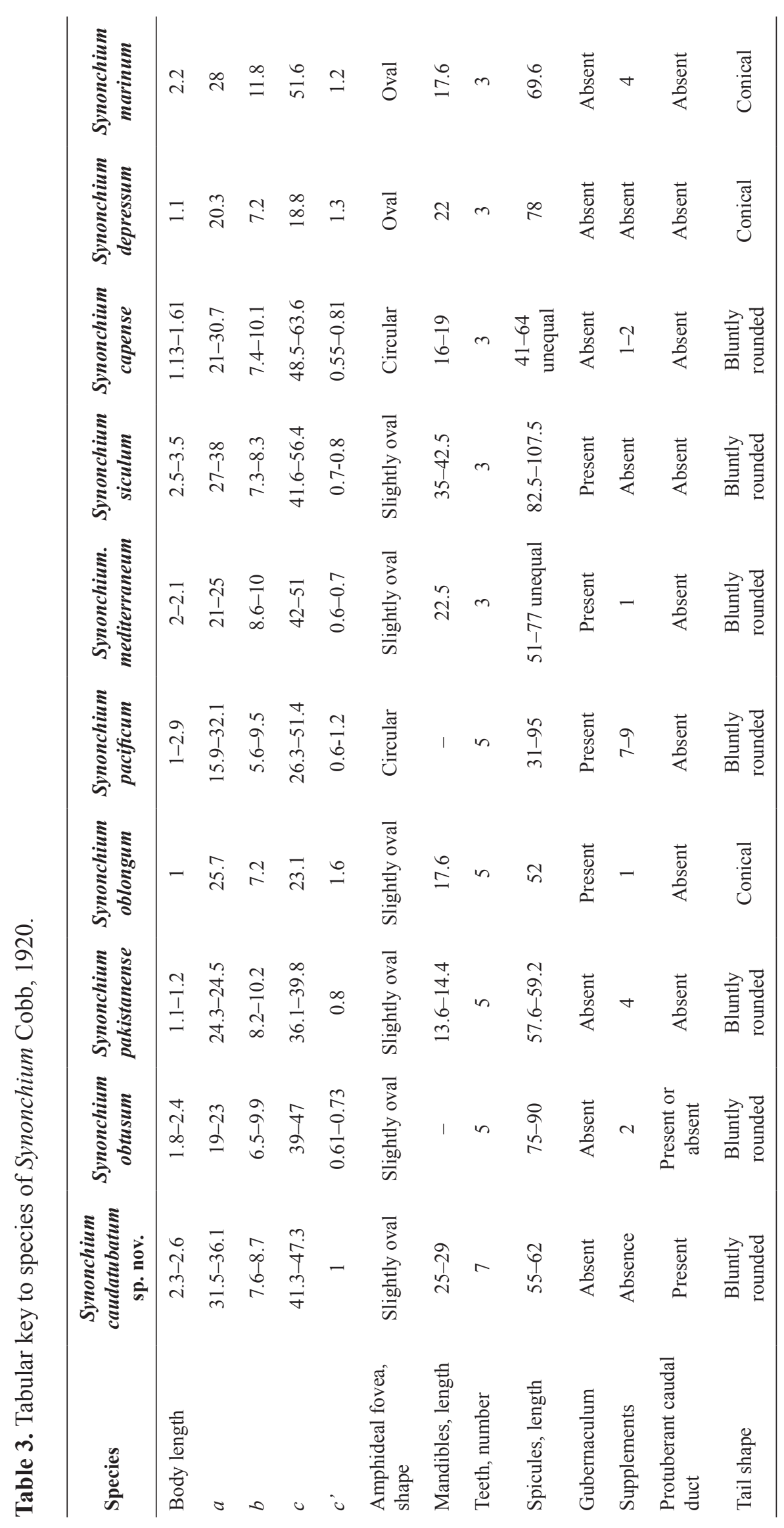






Fig. 5. Synonchium caudatubatum sp. nov., holotype, $\widehat{\partial}$ (A, C-F) and a paratype, $\subsetneq$ (B). A. Overview, showing the slightly slender body shape, the broad anterior buccal cavity and the narrow posterior buccal cavity with three mandibles, the cylindrical pharynx with anterior end swelling, the two opposed testes with oval sperm cells, the almost straight spicules without gubernaculum, the caudal glands with spinneret, and the bluntly rounded tail with a protuberant caudal duct. B. Overview, showing same structures as male holotype except the two reflexed ovaries. C. Each mandible has a large tooth flanked by three small teeth to each side. D-E. Head, showing the papillate sensilla, transverse oval amphideal fovea, transverse rows of punctuations, lateral cuticle pores, the broad anterior buccal cavity and the narrow posterior buccal cavity with three mandibles. F. Tail, showing the almost straight spicules without gubernaculum, the three caudal glands with spinneret, and the bluntly rounded tail with protuberant caudal duct. Scale bars: A-B, D-F $=50 \mu \mathrm{m}, \mathrm{C}=50 \mu \mathrm{m}$. 



Fig. 6. Synonchium caudatubatum sp. nov. holotype, $\hat{\sigma}(\mathrm{A}-\mathrm{C})$ and a paratype, $\hat{\sigma}$ (D). A-B. Head, showing the papillate sensilla, transverse oval amphideal fovea, transverse rows of punctuations, lateral cuticle pores, the broad anterior buccal cavity and narrow posterior buccal cavity with three mandibles each with seven teeth, and the swelling anterior end of pharynx. C. Tail, showing the almost straight spicules without gubernaculum, and the bluntly rounded tail with a protuberant caudal duct. D. Overview, showing the slightly slender body. Scale bars: $\mathrm{A}-\mathrm{C}=30 \mu \mathrm{m}, \mathrm{D}=100 \mu \mathrm{m}$. 
group occupying more than $60 \%$ of the nematode abundance. Members of Thoracostomopsidae are mostly large and predatory and thus may be significant in the sand beach due to their high dominance (Shi \& Xu 2016). Selachinematidae contributed to only about $4.6 \%$ of the total nematode abundance. However, the two selachinematid species described here are more rapacious nematodes feeding on other nematodes, including members of Thoracostomopsidae Filipjev, 1927. Thus, it can be assumed that Gammanema magnum sp. nov. and Synonchium caudatubatum sp. nov. play a key role in regulating the micro- and meiobenthic communities of this sand beach environment.
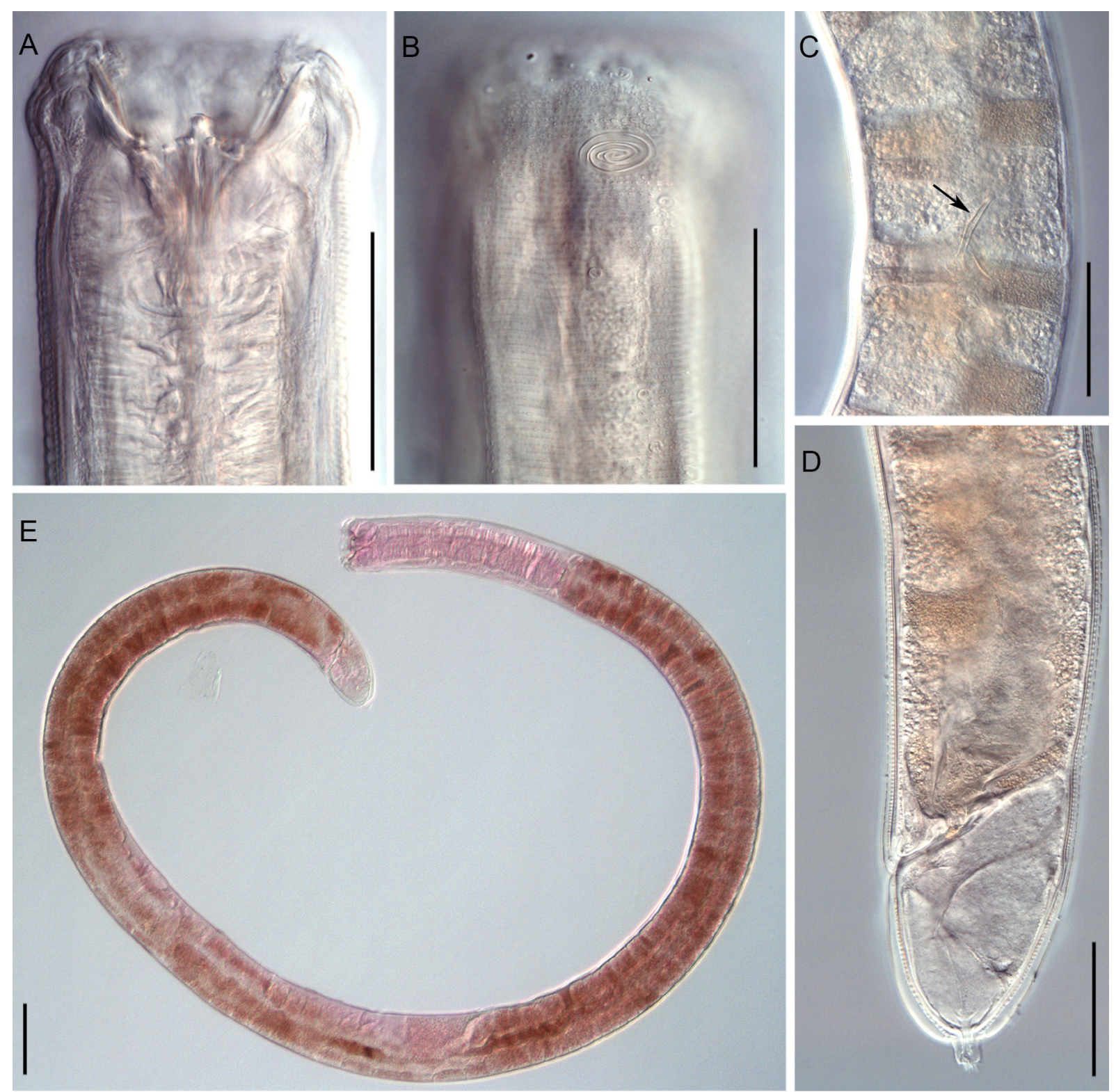

Fig. 7. Synonchium caudatubatum sp. nov., paratypes, $\circ$ +. A-B. Head, showing the same structures as male holotype. C. Spicules (arrow) of prey nematodes left in the intestine. D. Tail, showing the caudal glands with spinneret and the bluntly rounded tail with a protuberant caudal duct. E. Overview, showing the slightly slender body shape and two opposed testes. Scale bars: A-D $=50 \mu \mathrm{m}, \mathrm{E}=100 \mu \mathrm{m}$. 


\section{Acknowledgements}

This project was funded by the China Postdoctoral Science Foundation (2016M602201); the Community Structure of the Meiofauna and Evaluation on the Marine Environment in the Nanji Islands under official construction of the Nanji Islands National Marine Natural Reserve of the State Oceanic Administration of China (NJKJ2016-004) and the Laboratory for Marine Biology and Biotechnology, Qingdao National Laboratory for Marine Science and Technology.

\section{References}

Coomans A. 1979. Addendum I. A proposal for a more precise terminology of the body regions in the nematode. Annales de la Societé royale zoologique de Belgique 108: 155-117.

Fu S., Cai L., Boucher G., Cao J. \& Wu C. 2013. Two new Richtersia species from the northern Beibu Gulf, China. Journal of Natural History 47 (29-30): 1921-1931.

https://doi.org/10.1080/00222933.2013.769640

Gerlach S.A. 1964. Revision der Choniolaiminae und Selachinematinae (freilebende MeeresNematoden). Mitteilungen aus dem Hamburgischen Zoologischen Museum und Institut (KosswigFestschrift) 61: 23-49.

Gerlach S.A. \& Riemann F. 1973. The Bremerhaven checklist of aquatic nematodes. A catalogue of NematodaAdenophorea excluding the Dorylaimida. Veröffentlichungen des Instituts für Meeresforschung in Bremerhaven, Supplement 4 (1): 404.

Heyns J. \& Swart A. 1995. Synonchium capense n. sp. from South Africa (Nematoda: Cyatholaimidae). Fundamental \& Applied Nematology 18 (6): 523-529.

Higgins R.P. \& Thiel H. 1988. Introduction to the Study of Meiofauna. Smithsonian Institution Press, Washington DC.

Kamran M., Nasira K. \& Shahina F. 2009. Three new species of the genus Synonchium Cobb, 1920 (Chromadorida: Selachinematidae) from mangrove areas of Pakistan. Pakistan Journal of Nematology 27 (2): 129-144.

Leduc D. 2013. Two new genera and five new species of Selachinematidae (Nematoda, Chromadorida) from the continental slope of New Zealand. European Journal of Taxonomy 63: 1-32. https://doi.org/10.5852/ejt.2013.63

Liu R.Y. 2008. Checklist of Marine Biota of China Seas. Science Press, Beijing.

Miljutin D.M., Gad G., Miljutina M.M., Mokievsky V.O., Fonseca-Genevois V. \& Esteves A.M. 2010. The state of knowledge on deep-sea nematode taxonomy: how many valid species are known down there? Marine Biodiversity 40: 143-159. https://doi.org/10.1007/s12526-010-0041-4

Okhlopkov J.R. 2002. Free-living nematodes of the families Selachinematidae and Richtersiidae in the White Sea (Nematoda, Chromadorida). Zoosystematica Rossica 11: 41-55.

Okhlopkov J.R. 2003. Feeding of free-living nematodes of the families Selachinematidae and Richtersiidae in the White Sea. Proceedings of the Pertsov White Sea Biological Station 9: 127-139.

Platt H.M. \& Warwick R.M. 1983. Free-living Marine Nematodes. Part I: British Enoplids. Pictorial key to world genera and notes for the identification of British species. In: Kermack D.M. \& Barnes R.S.K. (eds) Synopses of the British Fauna (New Series) 28: 169-171. Cambridge University Press, Cambridge.

Shi B. \& Xu K. 2016. Four new species of Epacanthion Wieser, 1953 (Nematoda: Thoracostomopsidae) in intertidal sediments of the Nanji Islands from the East China Sea. Zootaxa 4085 (4): 557-574. https://doi.org/10.11646/zootaxa.4085.4.6 
SHI B. \& XU K., Two new rapacious nematodes from an intertidal flat

Tchesunov A.V. \& Okhlopkov J.R. 2006. On some selachinematid nematodes (Chromadorida: Selachinematidae) deposited in the collection of the Smithsonian National Museum of Natural History. Nematology 8: 21-44. https://doi.org/10.1163/156854106776179890

Vanaverbeke J. 2015. Selachinematidae Cobb, 1915. In: Guilini K., Bezerra T.N., Eisendle-Flöckner U., Deprez T., Fonseca G., Holovachov O., Leduc D., Miljutin D., Moens T., Sharma J., Smol N., Tchesunov A., Mokievsky V., Vanaverbeke J., Vanreusel A., Venekey V. \& Vincx M. 2017. NeMys: World Database of Free-Living Marine Nematodes. Available from http://nemys.ugent.be/aphia. php? $\mathrm{p}=$ taxdetails\&id=2166 [accessed 2 Jun. 2017].

Vinciguerra M.T. \& Orselli L. 1997. Nematodes from Italian sand dunes. 2. Four new and a rare species of Chromadoria. Nematologia Mediterranea 25: 261-270. Available from http://www.inaav.ba.cnr.it/ vol25-2,\%201997/vol25-2r.pdf [accesed 16 Jan. 2018].

Warwick R.M. 1971. Nematode associations in the Exe estuary. Journal of the Marine Biological Association of the United Kingdom 51: 439-454. https://doi.org/10.1017/S0025315400031908

Manuscript received: 1 April 2017

Manuscript accepted: 30 June 2017

Published on: 20 February 2018

Topic editor: Rudy Jocqué

Desk editor: Kristiaan Hoedemakers

Printed versions of all papers are also deposited in the libraries of the institutes that are members of the EJT consortium: Muséum national d'Histoire naturelle, Paris, France; Botanic Garden Meise, Belgium; Royal Museum for Central Africa, Tervuren, Belgium; Natural History Museum, London, United Kingdom; Royal Belgian Institute of Natural Sciences, Brussels, Belgium; Natural History Museum of Denmark, Copenhagen, Denmark; Naturalis Biodiversity Center, Leiden, the Netherlands; Museo Nacional de Ciencias Naturales-CSIC, Madrid, Spain; Real Jardín Botánico de Madrid CSIC, Spain. 